Effect of cell density on the rate of gl ycosami nogl ycan accumul at i on by di sc and cartil age cells in vitro

\begin{tabular}{|l|l|}
\hline 著者 & KOBAYASH Shi ger u, Adam MEI R, Ji I I URBAN \\
\hline $\begin{array}{l}\text { j our nal or } \\
\text { publ i cat i on t i t l e }\end{array}$ & Journal of Ort hopaedi c Resear ch \\
\hline vol une & 26 \\
\hline number & 4 \\
\hline page range & $493-503$ \\
\hline year & $2007-11$ \\
\hline URL & ht t p: //hdl . handl e. net /10098/1849 \\
\hline
\end{tabular}




\title{
The effect of cell density on the rate of glycosaminoglycan accumulation by disc and cartilage cells in vitro
}

Shigeru Kobayashi, ${ }^{1,2} \cdot$ Adam Meir, $^{1} \cdot$ Jill Urban $^{1}$

${ }^{1}$ Department of Physiology, Anatomy and Genetics, Oxford University, Parks Road, Oxford, OX1 3PT,UK

${ }^{2}$ Department of Orthopaedics and Rehabilitation Medicine, Faculty of Medical Sciences, The University of Fukui, 23-3,_Shimoaizuki, Matsuoka, Yoshida, Fukui, 910-1193, Japan

Corresponding author: Shigeru Kobayashi

Department of Orthopaedics and Rehabilitation Medicine, Faculty of Medical Sciences, The University of Fukui, Shimoaizuki 23, Matsuoka, Fukui, 910-1193, Japan

E-mail: kshigeru@u-fukui.ac.jp

Tel.: +81-776-61-8383, Fax.: +81-776-61-8125

\section{Short title runninghead: CELL DENSITY EFFECT ON GAG ACCUMULATION}

\author{
Abstract \\ Aggrecan concentration falls markedly during cartilage and disc degeneration with unfortunate \\ biomechanical and physiological consequences. There is thus now an increasing interest in \\ developing biological methods for its replacement. One approach is to stimulate aggrecan and \\ hence glycosaminoglycan (GAG) production by resident cells through growth factor or genetic
}


engineering. Another approach is to implant autologous cells into the cartilage or disc to enhance GAG production. In both instances GAG accumulation depends both on the number of active cells in the cartilage or disc and the rate of aggrecan synthesis per cell. Here we examine how cell density influences the rate of glycosaminoglycan accumulation in a three-dimensional cell culture system. In the results, at cell densities found in vivo (standard condition) in the articular cartilage and the disc nucleus viz. 4 million cells $/ \mathrm{ml}$ and at $21 \%$ oxygen the concentration of GAG in the bead reached $520.9 \pm 62.4 \mu \mathrm{g} / \mathrm{ml}$ and $649.0 \pm 40.1 \mu \mathrm{g} / \mathrm{ml}$, respectively, in 5 days. These concentrations could be increased to $2-4$ fold by raising cell density to 25 million cells $/ \mathrm{ml}$. However, rates of GAG production per cell decreased by $50-60 \%$. These results showed that rate of accumulation of glycosaminoglycan in this culture systems in vitro is slow and is limited both by the rate of production of GAG per cell and by the cell density which can be maintained in a viable state. Although GAG production can be increased somewhat by use of higher cell densities, the consequent fall in concentration of oxygen and other nutrients in the centre of three-dimensional constructs slows metabolism and leads to apoptosis and cell death, which again limits the rate that the cells can produce matrix.

Key words: Nucleus pulposus, Articular condrocyte, Tissue engineering, In vitro, Alginate 


\section{Introduction}

Proteoglycans, particularly the large aggregating proteoglycan aggrecan, play a major mechanical role in load-bearing cartilages. Aggrecan, on account of the high osmotic pressure resulting from its sulfated glycosaminoglycans, tends to imbibe water, inflate the collagen network and maintain tissue turgor. The stiffness of cartilaginous tissues is thus strongly dependent on aggrecan content. A fall in proteoglycan concentration is one of the first changes in osteoarthritis and disc 
degeneration $[1,2]$ with consequent deleterious effects on the mechanical behaviour of these tissues. There is now an increasing interest in developing biological methods of cartilage repair for these disorders [3] with attainment of the correct biomechanical properties critical for success. One of the targets of successful repair is thus that glycosaminoglycan concentration (GAG) of the tissueengineered construct should approach that of the native cartilage. GAG production however invariably takes months to approach concentrations equivalent to those found in cartilage. Consequently, numerous studies have attempted to increase the rate of GAG accumulation and cell proliferation in cartilaginous constructs by adding growth factors, altering environmental factors $\underline{\text { such as mechanical stress or oxygen levels and examining responses to various construct materials }}$ or designs [4-9]

GAG accumulation in constructs is dependent on the rate of GAG production per cell and on the cell density. It seems intuitive therefore that increasing cell density should increase rate of GAG deposition, as indeed has been shown in several studies [10-14]. However it is apparent from these $\underline{\text { studies that GAG accumulation in the construct does not increase in proportion to cell density and }}$ indeed GAG production per cell appears to fall at high cell densities. We suggest that in three dimensional constructs, nutritional demands restrict activity at high cell densities. Here we have investigated this aspect using two different cartilaginous cell types of interest in biological reconstruction i.e. cells from nucleus pulposus and from articular cartilage. We used alginate gels in the form of beads as a model system so that cells could be recovered readily. We mainly examined two initial seeding cell densities viz. $4-5$ million cells/ml and 25 million cells/ml; the lower density 
represents cell densities often used in alginate beads and found in vivo in the intervertebral disc nucleus and the higher cell density is that found in young adult cartilage from the bovine metacarpal-phalangeal joint. We examined both cell types at each cell density to investigate whether cell type influenced responses.

\section{Materials and methods}

\section{Materials}

All chemicals, apart from those detailed below, were obtained from BDH Laboratory Supplies, Poole Dorset. Dulbecco's modified Eagle's medium (DMEM) (cat.no 22320-022 with 25 mM Hepes, $1 \mathrm{mM}$ sodium pyruvate, $1000 \mathrm{mg} / \mathrm{L}$ glucose), foetal bovine serum (FBS) and antibiotics/antimycotics were obtained from Life Technologies Ltd., Paisley, Scotland. Collagenase-1, chondroitin-sulphate type A, twice-recrystrallised papain and the $20 \mu \mathrm{m}$ cell strainer were from Sigma-Aldrich, Poole, Dorset. The radiochemical used $\left({ }^{35} \mathrm{~S}\right.$-sulphate $)$ was from Amersham Biosciences, Little Chalfont, Bucks, UK. Sodium alginate was from Fluka Biochemika, Gillingham, Kent, UK. Dimethylmethylene blue was from Serva Feinbiochemica, Heidelberg, Germany. Scintillant (Ecoscint) was from National Diagnostics, Hull, UK. The Live/Dead Assay kit was from Molecular Probes, Cambridge Biosciences, Cambridge, UK. Dialysis sacs (12-14,000 Daltons molecular weight cut off) were from Medicell International Ltd, London, UK. 


\section{Cell isolation}

Bovine caudal discs and metacarpal phalangeal joints from 18-24 month old steers were obtained from a local abattoir within 2-3h of slaughter and dissected aseptically. Discs from 58 tails and cartilage from 16 feet were used for the experiments described here. The nucleus pulposus was removed from the upper five intervertebral discs of each tail and the pooled tissue digested enzymatically for $18-20$ hours at $37^{\circ} \mathrm{C}$ in an incubator under $95 \%$ air and $5 \% \mathrm{CO}_{2}$. The digestion medium consisted of DMEM containing $1 \mathrm{mg} / \mathrm{ml}$ collagenase-1, antibiotics/ antimycotics (500 units $\mathrm{ml}^{-1}$ penicillin $\mathrm{G}, 500 \mu \mathrm{g} \mathrm{ml} \mathrm{g}^{-1}$ streptomycin sulphate and $25 \mu \mathrm{g} \mathrm{ml}^{-1}$ amphotericin B) made to 400 mOsm with $\mathrm{NaCl}$. The articular cartilage was removed from the joints using a scalpel, pooled and digested similarly. After incubation, the digested tissue suspensions were filtered initially through a coarse filter to remove undigested tissue and then through a $20 \mu \mathrm{m}$-pore cell-strainer. The cells in the filtrate were then washed three times by repeated centrifugation $(1000 \mathrm{Xg}$ for $5 \mathrm{mins})$ and resuspension in DMEM. The cell suspension was assessed manually using a haemocytomer and trypan blue exclusion for cell viability and cell number. Only cell preparations with cell viabilities $>95 \%$ were then used.

\section{Cell culture}

The cells were encapsulated in alginate beads. Briefly, the washed nucleus cells or articular chondrocytes were resuspended uniformly into $1.2 \%$ low viscosity alginate at controlled cell densities by gentle pipetting. Microspheres were then formed by expressing the cell suspension 
through a $21-\mathrm{G}$ needle attached to a $5 \mathrm{ml}$ syringe into a $102 \mathrm{mM} \mathrm{CaCl}_{2}$ solution. The microspheres were then washed twice with $25 \mathrm{ml}$ of $0.9 \% \mathrm{NaCl}$ solution and washed twice again with $25 \mathrm{ml}$ of DMEM. The beads were carefully placed into 48 well culture plates ( 5 beads per well); in each separate experiment, under each condition tested and at each time point, 3 wells were used for biochemical analysis, 3 for measurement of sulphate incorporation rate and one well for histological examination of the beads.

The multi-well plates were then incubated at $37^{\circ} \mathrm{C}$ in $1.0 \mathrm{ml}$ of $400 \mathrm{mOsm}-\mathrm{DMEM}$ containing $6 \%$ foetal bovine serum, $0.5 \%$ antibiotic/antimycotic and $0.5 \%$ gentamycin under $5 \% \mathrm{CO}_{2} / 95 \%$ air. The medium was changed every day and the lactate concentration in the medium measured. At each time point, the beads from 3 wells per experimental condition were labelled with ${ }^{35} \mathrm{~S}$-sulphate. Beads from another 3 wells were removed from the medium and weighed and dispersed in 3 volumes of citrate buffer containing $5 \mathrm{mM}$ cysteine hydrochloride and 0.56 unit/ml papain. Cell density and viability were determined microscopically on $20 \mu \mathrm{l}$ samples of the resulting solution using a haemocytomer and trypan blue exclusion. The number of live cells/bead was used for calculation of lactate production, GAG concentration and sulfate incorporation rate per million cells. The remaining solution was heated to $67^{\circ} \mathrm{C}$ overnight in a sealed tube to digest the proteoglycans. Aliquots of the solution were used for measurement of total glycosaminoglycan (GAG) accumulation and sulphate incorporation rate. The cell viability profile was examined across representative beads from the remaining well; remaining beads from this well were fixed, sectioned and examined histologically. 


\section{Glycosaminoglycan content}

Glycosaminoglycan (GAG) accumulation was measured using a modified dimethylmethylene blue (DMB) assay [15]. The absorbance of aliquots of the bead digest added to the DMB buffer was read at $595 \mathrm{~nm}$ using UV/VIS spectrophotometer (Lambda 5, Perkin-Elmer). GAG concentrations were estimated from a standard curve of chondroitin sulphate made up in $0.1 \%$ alginate in citrate buffer.

\section{Sulphate incorporation rates}

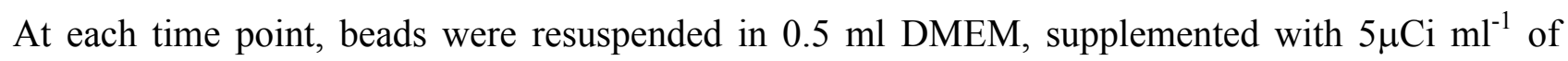
${ }^{35} \mathrm{SO}_{4}{ }^{2-}$ and incubated for a further $4 \mathrm{~h}$ at $37^{\circ} \mathrm{C}$ and $5 \% \mathrm{CO}_{2}$. Radiolabeling was stopped by washing the beads twice in ice-cold PBS supplemented with $2 \mathrm{mM} \mathrm{CaCl} 2,5 \mathrm{mM} \mathrm{Na}_{2} \mathrm{SO}_{4}$ at $4^{\circ} \mathrm{C}$ and then freezing at $-20^{\circ} \mathrm{C}$. Labelled alginate beads were defrosted and digested in $0.5 \mathrm{ml}$ of PBS and $0.5 \mathrm{ml}$ of citrate buffer. The solution was then exhaustively dialysed to separate the bound and free ${ }^{35} \mathrm{SO}_{4}{ }^{2-}$. The dialysate and tubing were then placed into a scintillation vial and $4 \mathrm{ml}$ of scintillant (Ecoscint, National Diagnostics, Hull, UK) was added. The activity of the dialysate and $20 \mu$ samples of the incubation medium were measured on a beta scintillation counter.

Rates of sulphated GAG synthesis were calculated as described previously assuming that the specific activity of the ${ }^{35} \mathrm{SO}_{4}{ }^{2-}$ sulphate was the same in the medium and in the incorporated GAGs.

\section{Lactate production rate}


Lactic acid production was used as a marker for cell metabolism as glycolysis is the major ATPgenerating pathway for both intervertebral disc cells $[16,17]$. Lactic acid production was measured using a commercial kit (Sigma-product no. 735-10) using lactate dissolved in DMEM as a standard.

\section{Cell viability profiles}

The cell viability profile across intact beads was determined by manual counting using a Live/Dead assay kit containing two fluorescent probes, Ethidium homodimer-1 and Calcein A. Ethidium homodimer-1 cannot penetrate live cells but stains the DNA of dead cells red. Calcein-AM penetrates live cells where an esterase cleaves the molecule which then fluoresces green - dead cells contain no esterase. In order to visualise cells, the beads were cut in half using a blade and soaked in the Live/Dead solution for 1 hour. Their diameter was estimated microscopically and from their weight. They were then examined under a Bio-Rad MRC 1024 confocal microscope equipped with a 15-milliwatt Krypton argon laser. The number of live (green) and dead (red) cells were counted manually in the peripheral and central portions in the bead. At least 4 fields each containing at least 15 cells was counted in each area. The proportion of live and dead cells was then calculated from pooled results.

\section{Measurement of GAG profiles.}

Beads were fixed in $4 \%$ paraformaldehyde with $2 \mathrm{mM} \mathrm{CaCl}_{2}, 5 \mathrm{mM} \mathrm{Na}_{2} \mathrm{SO}_{4}$ at $4^{\circ} \mathrm{C}$ for 4 hours and stored in the $50 \mathrm{mM} \mathrm{BaCl} 2$ solution (0.1M cacodylate buffer, $\mathrm{pH} 7.4)$. Before cutting, the beads 
were snap-frozen in hexane/dry-ice and $20-\mu \mathrm{m}$ sections were cut using a cryostat and placed on gelatine-coated slides. Citrate buffer was then added to the sections to remove the alginate gel and the sections washed with PBS. The sections were then stained with $1 \%$ alcian blue in $3 \%$ acetic acid for 30 minute, again washed in PBS and then counter-stained in hemetoxylin and eosin. After dehydration, the sections were mounted in DPX mountant without counterstaining, and examined under a standard light microscope $400 \mathrm{X}$ objective. Images were captured digitally and the GAG around cells was quantified using image-analysis (Scion image, Scion Co., Maryland). The fraction of stained area was compared in the peripheral and central regions of the beads.

\section{Transmission Electron Microscopicy}

Beads were fixed by immersion in $2.5 \%$ glutaraldehyde $(0.15 \mathrm{M}$ cacodylate buffer, $\mathrm{pH} 7.2)$ with $2 \mathrm{mM} \mathrm{CaCl}_{2}, 5 \mathrm{mM} \mathrm{Na}_{2} \mathrm{SO}_{4}$ at $4{ }^{\circ} \mathrm{C}$ for 4 hours. After fixation, the samples were washed for 3 days in sucrose and then sliced at approximately $50 \mu \mathrm{m}$ thickness using a cryostat. The specimens were then rinsed in $0.05 \mathrm{M}$ Tris- $\mathrm{HCl}$ buffer, postfixed at room temperature for 3 hours in $2 \% \mathrm{OsO}_{4}$ in $0.1 \mathrm{M}$ sodium cacodylate buffer, impregnated with $2 \%$ uranyl acetate, dehydrated in graded ethanols and embedded in Epoxy resin. For electron microscopy, ultrathin sections contrasted with uranyl acetate and lead citrate were examined under JSM2000FX electron microscope.

\section{Statistical analysis}


Unless otherwise stated, data are presented as the mean \pm the standard error of the mean (SEM) of at least three separate experiments $(n \geq 3)$. Each experiment was carried out in triplicate. Significant differences of prior comparison was determined using a 2 way ANOVA with repeated measures. When interaction was positive, we used student $t$ test or paired $t$ test. Date were entered into a database and analysed by using SPSS statistical soft-ware, version 14.0.J (SPSS Inc, Chicago, IL). A probability of 5\% was considered statistically significant.

\section{Results}

\section{Comparison between nucleus pulposus cells and articular chondrocytes}

Nucleus pulposus cells accumulated noticeably more GAG than articular chondrocytes under all conditions (Figs 1,2). The difference increased with time in culture and also with increase in cell density though it appeared to diminish at very high cell densities.

\section{Effect of cell density on increase in glycosaminoglycan concentration and accumulation per cell with time in culture}

The amount of GAG accumulated in a typical culture of articular chondrocytes and nucleus pulposus cells increased with time in culture. After 7 days a bimodal response was evident with the

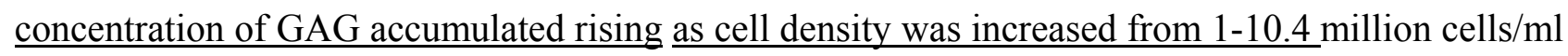
and then falling gradually as cell density was further increased (Fig.1A). However the GAG production per million cells fell as cell density was increased (Fig.1B). 
$\underline{\text { Significantly more GAG was accumulated by cells cultured at high ( } 25 \text { million cells } / \mathrm{ml}) \text { than low }}$ $(4$ million cells $/ \mathrm{ml})$ densities $(\mathrm{P}<0.05)$ and in agreement with results shown in Fig.1, GAG accumulated also increased with time in culture (Fig.2). At 4 million cells $/ \mathrm{ml}$, the concentration of GAG in the bead reached $520.9 \pm 62.4 \mu \mathrm{g} / \mathrm{ml}$ and $649.0 \pm 40.1 \mu \mathrm{g} / \mathrm{ml}$, respectively, in 5 days. These $\underline{\text { concentrations could be increased to } 1297.2 \pm 115.2 \mu \mathrm{g} / \mathrm{ml} \text { and } 2641.5 \pm 562.0 \mu \mathrm{g} / \mathrm{ml} \text { by raising cell }}$ density to 25 million cells/ml (Fig.2A,C). The increase in amount of GAG accumulated was not directly proportional to increase in cell density; although the beads at high cell density contained more than 6 times as many cells as those at low cell density, they only produced only 2-3 times as much total GAG (Fig 2B,D). After 5 days culture at 4 million cells/ml, GAG accumulation per cell was $166.3 \pm 38.9 \mu \mathrm{g}$ GAG/million cartilage cells and $240.9 \pm 13.1 \mu \mathrm{g}$ GAG/million nucleus cells. $\underline{\text { These amounts fell to } 70.9 \pm 23.9 \mu \mathrm{g} / \text { million cartilage cells and } 86.3 \pm 12.7 \mu \mathrm{g} / \mathrm{million} \text { nucleus cells }}$ when cell density was increased to 25 million cells $/ \mathrm{ml}$. Thus, cells cultured at low density were $\underline{\text { more active and accumulated significantly more GAG per cell than cells cultured at high density }}$ $\underline{(\mathrm{P}<0.05)}$. Evidence of greater cellular activity for cells cultured at low cell density was also seen

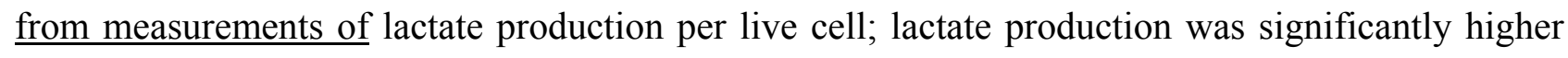
for nucleus cells cultured at low density than for those cultured at high density (Fig 3A). Lactate production also decreased with time in culture $(\mathrm{P}<0.05)$, more rapidly at high than at low cell densities. The rate of sulphate incorporation per live cell was also greater at low than at high cell densities (Fig.3B), though the difference was less marked than that seen in Fig.3A; sulphate 
incorporation fell more steeply than lactate production with time in culture $(\mathrm{P}<0.05)$. Similar results were seen for articular chondrocytes (Fig 3).

\section{Comparison between GAG accumulated in the bead centre and bead periphery.}

From sections of beads cultured for 7 days at 25 million cells $/ \mathrm{ml}$ and then stained with Alcian blue to visualise the sulphated GAGs accumulated (Fig.4A-C), there was a noticeable difference between staining at the bead periphery (Fig.4B) and the bead centre (Fig.4C). From densitometric

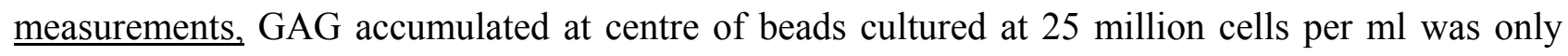
$60-70 \%$ of that accumulated at the periphery $(\mathrm{P}<0.05)$ (Fig.4D). Less staining was seen in beads cultured at 4 million cells per $\mathrm{ml}$ as seen also from chemical analysis (Fig.2). At this low density however there was no significant profile of GAG accumulation across the bead, with the amount accumulated in the centre similar to that accumulated at the periphery. Similar results were seen for beads containing articular chondrocytes.

\section{Cell viability across the beads.}

The change in percentage of live and dead cells with time in culture at the periphery and centre of beads is shown in Fig.5A for cells cultured at low (4 million cells/ml) and high cell densities (25 million cells $/ \mathrm{ml}$ ), respectively. It can be seen that by day 2 of culture at high cell densities, while almost all the cells at the periphery were alive, c.30 percent of the cells in the bead centre were dead. Similar percentages were dead at day 5 of culture, suggesting the profile of viable cells across the 
bead was established early in culture (Fig.5B,C). For cells cultured at 4 million cells $/ \mathrm{ml}$, c. $100 \%$ of the cells were viable at the both the periphery (Fig 5D) and in the centre (Fig 5E). Similar results at both high and low densities were seen for cartilage cells (Fig.5F-H).

At low cell density, transmission electron micrographs indicated that all cells, independent of location in the bead, appeared viable and active, with large nuclei, dotted with chromatin and abundant rough endoplasmic reticulum (Fig.6A,E). Nucleus cells cultured at high cell density, appeared viable at the bead periphery (Fig.6B). However cells undergoing apoptosis were seen in the centre (Fig.6C); the cells and nuclei were reduced in size and chromatin condensation was visible in the nuclei. Cells with condensed and fragmented nuclei and condensed chromatin (apoptotic bodies) and with cytoplasmic organelles destroyed were visible (Fig.6D). Similar results were seen for articular chondrocytes (Fig.6E,F).

\section{Discussion}

The results show that the when chondrocytes or nucleus cells were cultured in three-dimensional constructs such as alginate beads, the amount of glycosaminoglycan accumulated increased with time in culture and also with increase in cell density as expected (Figs. 1A,2A,2C). However the rise in cell density did not lead to a proportional rise in the amount of GAG accumulated; rather the amount of GAG produced per live cell fell with cell density (Fig.1B) and was significantly lower in beads cultured at a density of 25 million cells per $\mathrm{ml}$ than in those cultured at 4 million cells per $\mathrm{ml}$ for both cartilage and disc cells (Figs.2B,2D). This difference arose at least in part from a fall in 
metabolic activity of the cells rather than because of increased loss of GAG; the rate of energy production and of sulphated GAG production/viable cell (Fig.3B) was lower in cells cultured at high cell densities.

The results also showed that at high cell densities, less GAG was produced in the centre of the bead than at the bead periphery (Fig.4), possibly because within 48 hours of culture, a significant proportion of the cells in the centre of the bead showed apoptotic changes (Figs.6C,D,F) or were dead. At the bead periphery on the other hand, all cells appeared viable (Fig.6B). At low cell density, no such profiles in GAG production or cell viability were observed; all cells appeared viable (Figs.6A,6E). These results are in agreement with those of others who have found regions of cell death in the centre of constructs or even of microsphere aggregates [18-20] and that GAG accumulation was highest at the construct peripheries. In addition, others have also found that increasing cell density or cell number does not necessarily increase matrix accumulation [19].

These avascular constructs, unless experimentally perfused, rely on diffusion for supply of nutrients to the cells $[21,22]$ simulating the condition seen in articular cartilage and intervertebral disc. In avascular tissues and in constructs, there are steep gradients of oxygen and other nutrients between the surface and centre of the tissue or constructs $[23,24]$. The steepness of these gradients, and hence the nutrient concentrations in the centre of the construct, depend not only on the geometry and properties of the tissue or construct but also on the cell density and the cellular activity [25-27]. Thus in any particular construct or tissue an increase in cell density will lead to a corresponding fall in the concentration of nutrients such as oxygen and glucose and an increase of 
metabolic by-products such as lactic acid [26] leading, once cell density has risen sufficiently, to a fall in rates of cell metabolism and GAG synthesis [28,29]. If cell density is sufficiently great, oxygen and glucose concentrations and $\mathrm{pH}$ levels can fall to levels which can no longer sustain viable cells [30], leading to the necrotic region in the construct centre. Diffusional nutrient transport is thus a limitation on the number of viable and active cells which can be maintained in any construct or tissue; indeed viable cell density is inversely related to diffusion distance both in cartilage and in constructs [30,31].

The inter-relationships between cell density, cell viability and activity, and diffusion distance resulting from nutrient supply constraints, limit the rate at which GAG can be accumulated in threedimensional constructs. GAG accumulation depends on GAG production per cell and on cell density. At low cell densities, cells may be functioning optimally but the low cell density limits the rate of GAG accumulation. At high cell densities, more GAG is deposited at least initially, but nutrient gradients particularly in the centre of constructs, reduce the rate of GAG deposition per cell and may even lead to a fall in cell number if cells die.

GAG accumulation thus appears necessarily slow and the general finding that cultures of $>7$ months [22] are required to achieve concentrations of GAG similar to those seen in vivo may not be easily overcome [32]. The different manoeuvres which have been tried to increase GAG production all have limitations. An increase in GAG production rate per cell can be induced by addition of growth factors, by providing mechanical or ultrasound stimulation or through alterations to scaffold properties [33-36] but the relative increase which can be achieved is limited (usually 2-3 fold under 
optimal conditions) and the consequent increase in metabolic demand can lead to a fall in $\mathrm{pH}$ in the construct centre [37] and thus severely limit growth factor efficacy. Indeed addition of IGF-1 to constructs was found to have little effect on the concentration of accumulated GAG although it increased construct size [22]. In addition, as seen here (Fig.2), GAG production rates appear to fall with time in culture in many different systems also limiting GAG accumulation [38]. Increasing cell density potentially should increase GAG deposition as we found here for the initial period of matrix synthesis (Figs.1-3), but leads to a lower activity per cell and also in general, has not been found to increase GAG deposition rates [39]. It should also be noted that tissue in vivo cannot support too high a cell density, so in vitro culture of constructs at high cell density could lead to cell death after implantation. Culture conditions such as stirring or perfusion [40,41] appear able to overcome diffusive transport initially, but as GAG concentrations rise and the hydraulic permeability of the construct falls, convective transport also is reduced and rates of GAG deposition slow. GAG concentrations were reported to reach $5 \%$ by wet weight within 2 months but took a further 5 months to increase to $7 \%$ GAG.

In view of the long culture times which appear necessary to achieve the required GAG composition in vitro, achievement of an vivo concentration before implantation of a construct may be an unrealistic and possibly unnecessary goal for tissue engineered cartilage. Cellular repair using autologous chondrocyte transplantation appears successful even though chondrocytes are implanted with no matrix at all. Under these conditions, remodelling in vivo appears to produce a cartilagetype matrix under some conditions. Tissue engineered composites implanted with low GAG 
appeared to accumulate GAG in vivo, withstand physiological loading and remodel towards a hyaline-type matrix. Perhaps optimisation of such processes is a more useful goal.

\section{Acknowledgement}

The submitted manuscript does not contain information about medical devices or drugs. No benefits in any form have been received or will be received from a commercial party related directly or indirectly to the subject of this article. This paper was presented at the $51^{\text {th }}$ Orthopaedic Research Societies (ORS). The authors thank Dr. Sajjad Razaq, Mrs. Heather Horner, Dr. Olga Boubriak, and Dr. Bob Lee for their dedicated assistance in this study. JU was supported by an Arthritis Research Campaign Senior Fellowship.

\section{Refferences}

1. McDevitt CA, Muir H. 1976. Biochemical changes in the cartilage of the knee in experimental and natural osteoarthritis in the dog. J Bone Joint Surg [Br] 58: 94-101.

2. Venn M, Maroudas A. 1977. Chemical composition and swelling of normal and osteoarthrotic femoral head cartilage. I. Chemical composition. Ann Rheum Dis 36:121-129. 
3. Schaefer D, Martin I, Jundt G, et al. 2002. Tissue-engineered composites for the repair of large osteochondral defects. Arthritis Rheum 46: 2524-2534.

4. Akeda K, An HS, Pichika R, et al. 2006. Platelet-rich plasma (PRP) stimulates the extracellular matrix metabolism of porcine nucleus pulposus and anulus fibrosus cells cultured in alginate beads. Spine 31:959-966.

5. Blunk T, Sieminski AL, Gooch KJ, et al. 2002. Differential effects of growth factors on tissueengineered cartilage. Tissue Eng 8:73-84.

6. Elisseeff J, McIntosh W, Fu K, et al. 2001. Controlled-release of IGF-I and TGF-beta-1 in a photopolymerizing hydrogel for cartilage tissue engineering. J Orthop Res 19:1098-1104.

7. Mauck RL, Nicoll SB, Seyhan SL, et al. 2003. Synergistic action of growth factors and dynamic $\underline{\text { loading for articular cartilage tissue engineering. Tissue Eng 9:597-611. }}$

8. Sohier J, Hamann D, Koenders M, et al. 2007. Tailored release of TGF-betal from porous $\underline{\text { scaffolds for cartilage tissue engineering. Int J Pharm 332:80-89. }}$

9. Yasuda A, Kojima K, Tinsley KW, et al. 2006. In vitro culture of chondrocytes in a novel thermoreversible gelation polymer scaffold containing growth factors. Tissue Eng 12:1237$\underline{1245 .}$

10. Almarza AJ, Athanasiou KA. 2005. Effects of initial cell seeding density for the tissue engineering of the temporomandibular joint disc. Ann Biomed Eng 33:943-950. 
11. Mauck RL, Seyhan SL, Ateshian GA, et al. 2002. Influence of seeding density and dynamic deformational loading on the developing structure/function relationships of chondrocyte-seeded agarose hydrogels. Ann of Biomed Eng 30:1046-1056.

12. Mauck RL, Wang CC, Oswald ES, et al. 2003. The role of cell seeding density and nutrient supply for articular cartilage tissue engineering with deformational loading. Osteoarthritis Cartilage 11:879-890.

13. Saini S, Wick TM. 2003. Concentric cylinder bioreactor for production of tissue engineered cartilage: effect of seeding density and hydrodynamic loading on construct development. Biotechnol Prog 19:510-521.

14. Williams GM, Klein TJ, Sah RL. 2005. Cell density alters matrix accumulation in two distinct fractions and the mechanical integrity of alginate-chondrocyte constructs. Acta Biomater 1:625633.

15. Farndale RW, Buttle DJ, Barrett AJ. 1986. An improved quantitation and discrimination of sulphated glycosaminoglycans by use of the dye dimethylmethylene blue. Biochem Biophys Act $883 ; 173-177$.

16. Holm S, Maroudas A, Urban JP, et al. 1981. Nutrition of the intervertebral disc: solute transport and metabolism. Connect Tissue Res 8: 101-119.

17. Lee RB, Urban JP. 1997. Evidence for a negative Pasteur effect in articular cartilage. Biochem J $\underline{321: 95-102 .}$ 
18. Martin I, Obradovic B, Freed LE, et al. 1999. Method for quantitative analysis of glycosaminoglycan distribution in cultured natural and engineered cartilage. Ann Biomed Eng 27: 656-662.

19. Mercier NR, Costantino HR, Tracy MA, et al. 2004. A novel injectable approach for cartilage formation in vivo using PLG microspheres. Ann Biomed Eng 32:418-429.

20. Obradovic B, Carrier RL, Vunjak-Novakovic G, et al. 1999. Gas exchange is essential for bioreactor cultivation of tissue engineered cartilage. Biotechnol Bioeng 63:197-205.

21. Grunhagen T, Wilde G, Soukane DM, et al. 2006. Nutrient supply and intervertebral dic metabolism. J Bone Joint Surg Am 88 Suppl 2:30-35.

22. Obradovic B, Meldon JH, Freed LE, et al. 2000. Glycosaminoglycan deposition in engineered cartilage: Experiments and mathematical model. Aiche Journal 46:1860-1871.

23. Kellner K, Liebsch G, Klimant I, et al. 2002. Determination of oxygen gradients in engineered tissue using a fluorescent sensor. Biotechnol Bioeng 80: 73-83.

24. Malda J, Rouwkema J, Martens DE, et al. 2004. Oxygen gradients in tissue-engineered PEGT/PBT cartilaginous constructs: measurement and modeling. Biotechnol. Bioeng. 86: 9-18.

25. Haselgrove JC, Shapiro IM, Silverton SF. 1993. Computer modeling of the oxygen supply and demand of cells of the avian growth cartilage. Am J Physiol 265: C497-C506.

26. Zhou S, Cui Z, Urban JP. 2004. Factors influencing the oxygen concentration gradient from the synovial surface of articular cartilage to the cartilage-bone interface: a modeling study. Arthritis Rheum 50: 3915-3924. 
27. Soukane DM, Shirazi-Adl A, Urban JP. 2005. Analysis of nonlinear coupled diffusion of oxygen and lactic acid in intervertebral discs. J Biomech Eng. 127:1121-1126.

28. Gray M, Pizzanelli A, Grodzinsky A, et al. 1988. Mechanical and physiochemical determinants of the chondrocyte biosynthetic response. J Orthop Res 6:777-792.

29. Ysart GE, Mason RM. 1994. Responses of articular cartilage explant cultures to different oxygen tensions. Biochim. Biophys Acta 1221:15-20.

30. Horner HA, Urban JP. 2001. Volvo Award Winner in Basic Science Studies: Effect of nutrient supply on the viability of cells from the nucleus pulposus of the intervertebral disc. Spine 26: 2543-2549.

31. Stockwell R. 1971. The inter-relationship of cell density and cartilage thickness in mammalian articular cartilage. J Anat 109:411-422.

32. Roughley PJ. 2004. Biology of intervertebral disc aging and degeneration: In volvement of the extracellular matrix. Spine 9:135-147.

33. Blunk T, Sieminski AL, Gooch KJ, et al. 2002. Differential effects of growth actors on tissueengineered cartilage. Tissue Eng 8:73-84.

34. Richmon JD, Sage AB, Shelton E, et al. 2005. Effect of growth factors on cell proliferation, matrix deposition, and morphology of human nasal septal chondrocytes cultured in monolayer. laryngoscope 115: 1553-1560. 
35. van der Kraan PM, Buma P, van Kuppevelt T, et al. 2002. Interaction of chondrocytes, extracellular matrix and growth factors: relevance for articular cartilage tissue engineering. Osteoarthritis. Cartilage 10: 631-637.

36. Kuo YC, Lin CY. 2006. Effect of genipin-crosslinked chitin-chitosan scaffolds with hydroxyapatite modifications on the cultivation of bovine knee chondrocytes. Biotechnol Bioeng 95:132-144.

37. Razaq S, Wilkins RJ, Urban JPG. 2003. The effect of extracellular pH on matrix turnover by cells of the bovine nucleus pulposus. Eur spine J 12:341-349.

38. Mercier NR, Costantino HR, Tracy MA, et al. 2004. A novel injectable approach for cartilage formation in vivo using PLG microspheres. Ann Biomed Eng 32:418-429.

39. Panossian A, Ashiku S, Kirchhoff CH, et al. 2001. Effects of cell concentration and growth period on articular and ear chondrocyte transplants for tissue engineering. Plast Reconstr Surg 108: 392-402.

40. Freyria AM, Ronzi S, Roche CF, et al. 2000. Regulation of growth, protein synthesis, and maturation of fetal bovine epiphyseal chondrocytes growth in high-density culture in the presence of ascorbic acid, retinoic acid and dihydrocytochalasin B. L Cell Biochem 76: 84-98.

41. Seidel JO, Pei M, Gray ML, et al. 2004. Long-term culture of tissue engineered cartilage in a perfused chamber with mechanical stimulation. Biorheology 41:445-458. 


\section{LEGENDS}

Fig.1: Typical results showing effect of cell density on GAG deposition (A) and on GAG accumulation per million cells (B) by articular chondrocytes and nucleus pulposus cells. 
Cells were isolated, encapsulated in alginate beads at cell densities ranging from 1 to 33 million cells $/ \mathrm{ml}$. Beads were cultured for 7 days at 5 wells/bead in $2 \mathrm{ml}$ medium, 2 wells for each cell density and cultured for 7 days in DMEM containing 6\% serum. Beads were then dissociated for cell counting and assay of total GAGs. Fig.2: Effect of cell density on GAG concentration (A,C) and GAG accumulation per million cells (B,D) by nucleus pulposus cells (A,B) and articular chondrocytes $(\mathrm{C}, \mathrm{D})$ after 2 days and 5 days in culture.

Cells were encapsulated in alginate beads, cultured in DMEM with 6\% serum under air and GAG concentration and cell density measured after 2 and 5 days culture. These figures give pooled data for the two representative cell densities from 3 separate experiments. Values are mean \pm standard error. $^{*}$ : Significant difference $(\mathrm{P}<0.05)$ between the high cell density $(25$ million cells $/ \mathrm{ml})$ and the low cell density (4 million cells/ml) using non-paired t test.

Fig.3: Effect of cell density on lactate production rate (A) and 35S-sulfate incorporation rate (B).

(A) Cells were cultured under standard conditions in beads containing 4 and 25 million cells/ ml (1.0ml medium, 5 beads/well) for up to 7 days, with complete medium change daily. Representative beads were dissociated for cell counting and viable cell density/bead recorded. Lactate in the medium was measured at days 1,5 and 7, after 24 hours culture and rates per million cells/24 hrs reported. High cell density lead to a fall in cellular metabolism $(*, * *, * * *,+,++,+++: \mathrm{P}<0.05$, Paired $\mathrm{t}$ test between high $[25$ million cells $/ \mathrm{ml}$ ] and low cell density [4 million cells $/ \mathrm{ml}]$ ). Lactate production rate fall with time in culture (\#: $\mathrm{P}<0.05,2$ way ANOVA with repeated measures among 1,5 and 7 days). 
(B) At days 1,5 and 7, tracer sulphate was added to the fresh medium of 3 wells, the beads were cultured in the radioactive solution for 4 hours, the beads dissociated and cell density and sulphate incorporation measured (Fig 3B). Results are given as means \pm s.e.m of 3 independent experiments. Sulfate incorporation rates fall with increase in cell density $(*, * *, * * *,+,++,+++: \mathrm{P}<0.05$, Paired $\mathrm{t}$ test between high [ 25 million cells $/ \mathrm{ml}]$ and low cell density [ 4 million cells/ml]) and with time in culture (\#: $\mathrm{P}<0.05,2$ way ANOVA with repeated measures among 1, 5 and 7 days).

Fig.4: Effect of cell density on GAG deposition by Alcian Blue staining after 5 days culture.

Fig 4A shows a 20micron section through a typical bead of nucleus cells cultured at 25 million cells/ml cultured for 5 days. Images at the periphery (Fig 4B) and at the centre (Fig 4C) were captured digitally and the GAG around cells was quantified using image-analysis. Results are reported as the fraction of stained area in the peripheral and central regions of the beads and data normalized to results at 25 million cells/ml (Fig 4D). At high cell density, the area of the staining was higher at the edge of the bead $(*,+: \mathrm{P}<0.05$, Paired $\mathrm{t}$ test between edge and centre). At low cell density, however, there was no significant profile of GAG accumulation between edge and centre $(* *: \mathrm{P}=0.712,++: \mathrm{P}=0.835$, Paired $\mathrm{t}$ test between edge and centre).

Fig.5: Effect of cell density on cell viability under conforcal microscope. 
(A-E) Nucleus pulposus cells. Fig 5A shows the variation of cell viability at the edge and centre of beads with time and cell density. Cell viability was determined using a live/dead assay kit; live cells (green) and dead cells (red) were counted manually. Results are means and s.e.ms of percentage of viable cell from 4 representative beads. At high cell density ( 25 million cells $/ \mathrm{ml}$ ), cell viability is lower in the centre than at the edge $(+: \mathrm{P}=0.961,++: \mathrm{P}=0.932, *, * *: \mathrm{P}<0.05,2$ way ANOVA with repeated measures between edge and centre). Figs 5B, 5C shows the periphery and central region respectively of a typical bead cultured at 4 million cells $/ \mathrm{ml}$ after 5 days. Figs 5D, 5E shows the periphery and central region of a bead cultured at 25 million cells $/ \mathrm{ml}$ after 5 days.

(F-H) Articular chondrocytes. Fig 5F shows the variation of cell viability with region (edge versus centre). At high cell density ( 25 million cells $/ \mathrm{ml}$ ), cell viability is lower in the centre than at the edge $(+: \mathrm{P}=0.977,++: \mathrm{P}=0.893, *, * *: \mathrm{P}<0.05,2$ way ANOVA with repeated measures between edge and centre). Figs 5G, 5H shows the periphery and central region respectively of a typical bead cultured at 25 million cells/ml after 5 days. Fig.6: Electron micrographs of central and peripheral nucleus pulposus cells (A-D) and articular chondrocytes (E,F) cultured at low and high cell density. The figures show representative cells from the central and peripheral regions of beads cultured at low (4million cells/ml) and high (25 million cells/ml) for 5 days. (A-D) nucleus pulposus cells, (EF) articular chondrocoytes. (A) Central region, low cell density, cells appear normal. (B-D) High cell density. (B) bead periphery, some cells appear normal. (25 million cells/ml), (C) central region showing cells undergoing apoptosis (arrows). The cells and nuclei were reduced in size and chromatin condensation was seen in the nuclei in comparison of the cells in the periphery. 
High power magnification of apototic nucleus pulposus cell. This picture shows apoptosis characterized by condensation and fragmentation of the nuclei (apototic body), chromatin condensation. (E) At low density, articular chondrocytes appear viable in the centre of the bead. (F) Central region showing high cell density chondrocytes undergoing apoptosis in the centre (arrows). The cells and nuclei were reduced in size and chromatin condensation was seen in the nuclei. 